\title{
Partition of digestion and performance of growing steers fed coast cross hay with three levels of concentrate
}

\author{
NM Rodriguez 1, TT Berchielli 2, P Andrade 2 \\ 'Escola de Veterinária da UFMG, CP 567, Belo Horizonte, Minas Gerais, Brasil; \\ 2UNESP, Jaboticabal, SP, Brasil
}

Three levels of concentrate (C) supplementation $(20 ; 40 ; 60 \%)$ to a low quality hay of coast-cross ( $F, 5.7 \% \mathrm{CP}$ ) were studied in a 90 days feedlot experiment with 18 growing steers $(300 \mathrm{~kg})$, and simultaneously in a partition of digestion experiment using three steers fitted with ruminal and duodenal cannulae in a $3 \times 3$ latin square design. Concentrate was made of $55 \%$ cottonseed meal and $45 \%$ corn grain plus urea to adjust rumen degradable nitrogen. Polyethylene glycol (PEG) and Co-EDTA were used as liquid-phase markers, ytterbium chloride and indigestible FDN as markers of solid phase, purines and ${ }^{35} \mathrm{~S}$ as markers of microbial protein. Volatile fatty acids (VFA) production was determined by infusium of $\mathrm{Na}$-acetate-14C (Weller et al, 1967, Austral J Agric Res, 18, 1, 107-108). PEG concentrations were determined by turbidimetry and ytterbium by atomic absorption spectrophotometry. Purines and ${ }^{35}$ S according to Zinn and Owens (1986, Can J Anim Sci, 66, 1, 157-166) and Mathers and Miller (1980, Br J Nutr, 43, 3, 503-514), respectively.

Organic matter apparently digested in the rumen (OMDR) increased with concentrate additions but decreased from 90 to 80 when expressed as percentage of apparent digestibility. Non ammonia nitrogen (NAN) flux to duodenum increased with concentrate, keeping a stable proportion of about $52 \%$ of bacterial nitrogen and relatively low mean efficiency of protein synthesis of $17 \mathrm{~g} \mathrm{Nm} / \mathrm{kg}$ OMDR. Total AGV production raised from 46 to 69 moles/day as concentrate increased in the ration. There was no correlation between acetate production and ruminal acetate concentration. Weight gain was highly correlated to metabolizable energy intake.

\begin{tabular}{|c|c|c|c|c|c|c|c|}
\hline Treatments $(F: C)$ & & $80: 20$ & & & $60: 40$ & & $40: \overline{60}$ \\
\hline DMI (g MS/kg0.75) & & $78.0^{a}$ & & & $91.0^{\circ}$ & & $91.8^{b}$ \\
\hline OMDR (kg/day) & & $2.0^{\mathrm{a}}$ & & & $2.5^{\mathrm{b}}$ & & $2.5^{\mathrm{b}}$ \\
\hline$N$ intake (g/day) & & $88.8^{a}$ & & & $133.2^{\mathrm{b}}$ & & $159.3^{b}$ \\
\hline Duodenal NAN (g/day) & & & & & & & \\
\hline total & & $53.5^{a}$ & & & $78.8 \mathrm{a}$ & & $89.3^{b}$ \\
\hline bacterial & & $28.8^{a}$ & & & $38.2^{a}$ & & $46.6^{a}$ \\
\hline ruminal $\mathrm{N}-\mathrm{NH}_{3}(\mathrm{mg} / 100 \mathrm{ml})$ & & 28.2 & & & 26.2 & & 21.3 \\
\hline VFA production(mol/day) & & & & & & & \\
\hline acetate & & $35.2^{\mathrm{a}}$ & & & $43.8 \mathrm{ab}$ & & $48.9^{b}$ \\
\hline propionate & & $7.0^{\mathrm{a}}$ & & & $9.4 \mathrm{~b}$ & & $13.0^{c}$ \\
\hline butyrate & & $4.0^{a}$ & & & $6.3^{\mathrm{b}}$ & & $6.8^{b}$ \\
\hline Weight gain (g/day) & & $436^{a}$ & & & $726^{\mathrm{b}}$ & & $757^{\mathrm{b}}$ \\
\hline
\end{tabular}

Means on the same row with different letters differ statistically $(P<0.05)$ 